\title{
Reptile distribution may identify terrestrial islands for conservation: the Levant's 'Arava Valley as a model
}

\author{
Merav Seifan ${ }^{a}$, Yaara Zohar ${ }^{b}$ and Yehudah L. Werner ${ }^{b, c}$ \\ aThe Mitrani Department of Desert Ecology, Swiss Institute for Dryland Environmental and Energy \\ Research, The Jacob Blaustein Institutes for Desert Research, Ben-Gurion University of the Negev, \\ Sde Boker Campus, Israel; 'bepartment of Ecology, Evolution and Behaviour, The Hebrew University of \\ Jerusalem, Jerusalem, Israel; 'Museum für Tierkunde, Senckenberg Dresden, Dresden, Germany
}

\begin{abstract}
Widely accepted major criteria for biodiversity hotspots that deserve conservation include species richness, endemism and threat. Proving that a taxon is endemic to a given area is more difficult, and therefore expensive, with animals than with plants because of the difficulty to prove absence outside the known distribution. Seeking a cost-efficient practical method to show animal endemism while funds necessary for conventional demonstration of endemism are lacking, we argued that when the known distribution of a suspected endemic taxon coincides with an ecogeographically isolated area, e.g. island, its exclusivity to that area is more credible. We selected a model site containing suspected endemics, the 'Arava depression (altitude - 400-0 m) between arid southern Israel and southern Jordan. A search of the literature and collections found at least 23 animal taxa endemic to the 'Arava, to the adjacent Dead Sea basin sharing the depression, or to both. We assessed the level of isolation of the 'Arava depression by statistically analysing the geographical distribution of taxa (species or subspecies) of one selected well researched model group, Squamata (lizards and snakes). In northern Israel and Jordan the squamate faunas of the two countries are very similar. In contrast in the south where the 'Arava intervenes, the two faunas greatly differ. The 'Arava both constitutes a partial barrier and is partly isolated. Hence its apparent endemics are likely real endemics, inviting conservation of the area. The more so since the 'Arava is also an arena of much research and education. Our methodology may serve worldwide to identify semi-isolated terrestrial areas for conservation.
\end{abstract}

\section{ARTICLE HISTORY}

Received 22 November 2015 Accepted 20 June 2016

\section{KEYWORDS}

Altitudinal isolation; cost-effective conservation; eco-geographical isolation; endemic animals; geographical distribution; reptiles

\section{Introduction}

Major criteria for defining biodiversity hotspots include species richness, endemism and also threat. For animals the safest and most widely used criterion is species-richness (Böhm et al. 2013). The measurements of the key criterion endemism are costly or doomed to remain uncertain because of the difficulty of proving a taxon's absence 
outside its known distribution. However, there are small areas that require conservation particularly for their local endemism (Myers et al. 2000; Orme et al. 2005), for example endemism resulting from their island-like isolation (Quinn and Harrison 1988). Unfortunately, funding for conservation of such areas often depends on proving their endangered situation convincingly, which requires evidence-gathering before any funding is directed to the specific area. Here we propose a practical strategy for how to bypass this obstacle. This is an acute facet of the quest for economical conservation (Mandelik et al. 2010).

Seeking an inexpensive and widely applicable way to satisfy this criterion we argued that when the known distribution of a taxon suspected to be endemic coincides with an eco-geographically isolated area, such as an island, the endemism of this taxon is more credible. As a test case we selected an area that according to its abiotic environmental variables appeared to be eco-geographically isolated and therefore probably harboured endemics, selected an animal group with known specific distribution ranges as a model for testing the area's isolation, and finally reviewed literature data on the distribution ranges of any animals suspected of being endemic to the test area. Our aims were twofold, and we achieved both: to pioneer a cost-efficient procedure for identifying zoogeographical terrestrial islands, marking them for conservation; and to assess the conservation priority of the 'Arava depression.

\section{Methods}

\section{The model area}

Our model site comes from the central Levant, politically comprising Israel, Jordan and the Palestinian Authority, and physically Cisjordan and Transjordan (Figure 1). Here several biogeographical regions meet. The contrast between the central Levant's mesic north, the Mediterranean (sensu stricto) and its arid south is conspicuous (Zohary 1973; Werner 1988; Yom-Tov and Tchernov 1988; Disi 1996). This is the southwestern tip of 'the fertile crescent' of the Near East (Sivan and Werner 2003). Perpendicularly to this north-south axis, the arid south is invaded by Saharan biota from the west and Arabian biota from the east (Werner 1987a, 1990a). Whether the area acts more as a bridge or as a filter between west and east is debatable (Werner 1993). Further enrichments come from infiltration of Irano-Turanian steppe elements, botanically considered to form a belt between the mesic Mediterranean and the arid SaharoArabian (Zohary 1973; Werner 1988; Yom-Tov and Tchernov 1988; Disi 1996). Additionally the south hosts an invasion, mostly recent, of Afro-tropical elements from further south (Shmida and Aronson 1986).

This inter-regional position has consequences. National biota have been considered species-rich relative to the area (Yom-Tov and Tchernov 1988; Yom-tov and Werner 1996) although this has been contested, arguing that small areas are relatively more species-rich than large ones (Roll et al. 2009, 2011; but see Yom-Tov 2011a, 2011b). Each of these four regional ecosystems includes some biogeographical heterogeneity (Yomtov and Werner 1996). For plants this heterogeneity was quantified by the phytogeographic revision of Danin and Plitmann (1987). Hence, in Cisjordan each ecosystem is at the edge of its geographic distribution and physical environment. Hence it is 


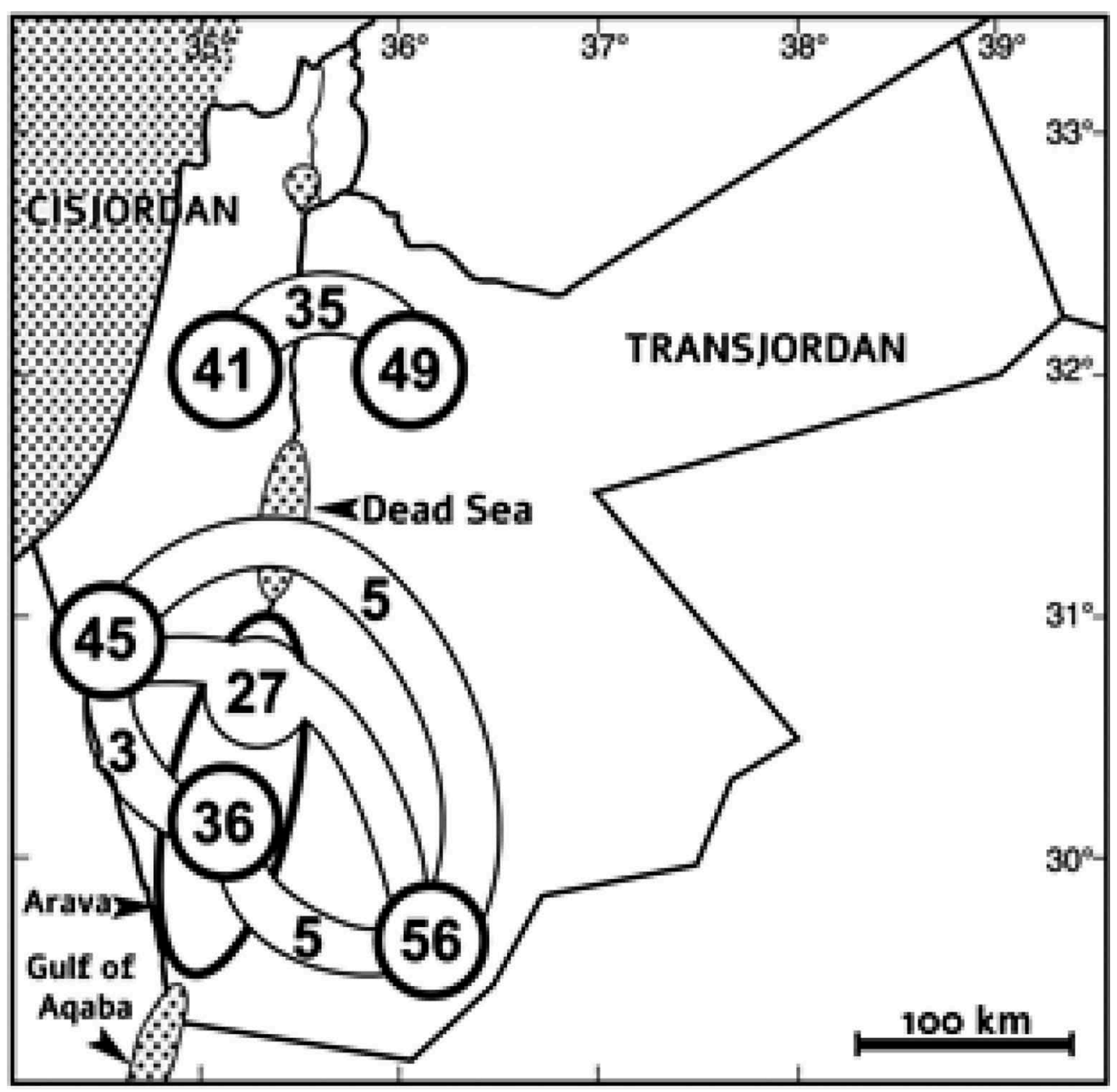

Figure 1. Schematic map of Cisjordan, Transjordan and the 'Arava valley shared by them. The number of squamate taxa in an area is encircled in that area. The number of species shared by two areas is in the arc bridging them. In the middle of the southern complex is a bridge joining all three areas. (Technique inspired by figures 92 and 95 in Anderson 1968).

vulnerable to local deterioration (Werner et al. 1998). However, local extinction of its elements may also be considered unimportant for global biodiversity.

Within this congregation of tips of ecosystems that extend widely outside the Levant (Werner 1987b, 2011; Werner and Sion 2008), local pockets of endemism have developed. One such pocket that has been researched and documented was the Hula Lake in the northern part of the Syrio-African Rift Valley (approx. $20 \mathrm{~km}$ north of the Sea of Galilee), to be discussed below in the Discussion.

Our selected test area is the 'Arava Valley (Wady Araba) further south in the SyrioAfrican Rift (approx. $125 \mathrm{~km}$ south of the Hula). It stretches from the Dead Sea (altitude approx. $400 \mathrm{~m}$ below sea level) to the Gulf of Elat (Gulf of Aqaba; altitude approx. sea level). Together with the Dead Sea basin, this depression is the warmest and driest part of Israel. Sharing altitude and climate the two share also some biota; both harbour 
Arabian and Afro-tropical plants and animals. But they differ ecologically: the Dead Sea is flanked on both sides by mountains and surrounded by perennial oases; the broad 'Arava contains extensive sand dune areas (Atlas of Israel 1985; Werner 1987a; Levin and Shmida 2007; Danin 2013).

\section{Exploring endemism}

In our literature search we targeted animal groups whose geographical range, as far as is known, was confined to the circumscribed depression of the 'Arava valley (or Dead Sea basin, or both). Furthermore we consulted experts of additional well studied groups about literature or collection-based data indicating 'Arava-endemism (see Acknowledgements). Finally we endeavoured to verify that indeed there were no later reports of the listed species occurring outside the depression.

\section{Testing isolation with a model group}

We hypothesized that the 'Arava represents an area that is important for conservation because it is isolated from the neighbouring deserts and so potentially serves as a meeting point for many taxa. This hypothesis derives from its physical and biological situation. Together with the Dead Sea basin it is a uniquely deep depression; the warmest and driest area in Israel. Besides sharing biota with surrounding areas, it seems to harbour also biota unique to itself. Although there are ecological differences between its eastern (Jordanian) and its more agriculturally exploited western (Israeli) parts (Shanas et al. 2006), we treated the whole as a unit. To test our hypothesis we examined the geographic distribution across the 'Arava of taxa of a model group, Squamata, i.e. lizards and snakes.

The choice of Squamata as a model group was based on the amount of information available in the literature on these animals, both in relation to their biology and to their geographical distribution (Werner 2016; and references hereinafter). Lizards have long served as ecological models (Milstead 1967; Huey et al. 1983; Vitt and Pianka 1994; Reilly et al. 2007). The snakes are phylogenetically positioned within the lizards (Townsend et al. 2004; Wiens et al. 2012). Nevertheless, snakes differ from lizards in morphological, physiological and ecological aspects: particularly, their locomotor abilities (Gans 1970), more eurythermal habits (Brattstrom 1965) and wider eco-geographical ranges (Shacham et al. 2009, 2015). We excluded the chelonians, not because their being reptiles has been (erroneously) contested (Collins et al. 2010), but because their response to environmental gradients differs, as reflected by their concordance with Bergmann's Law, unlike squamates (Ashton and Feldman 2003; Werner et al. 2015).

Lizards and snakes supply adequate distribution information because many are kept and recorded in museums (Babocsay et al. 2006). They get there following diverse accession procedures, from planned research to amateur donations and road kills, providing a wide survey with little bias. Moreover, within the biodiversity hotspot of the Mediterranean basin (Myers et al. 2000) the coastal Levant is relatively reptile-species rich (Böhm et al. 2013). This is partly due to the local herpetofaunal knowledge having advanced in recent decades through research (Werner 1968, 2004, 2007; Kark et al. 1997; Werner et al. 1999, 2006; Babocsay 2003; Baha El Din 2007; Perry 2012, 2012) and reviews 
(Hurvitz et al. 1980; Werner 1982, 1988, 1995, 1998; Sivan and Werner 1992; Amr et al. 1994; Amitai and Bouskila 2001; Disi 2002, 2011; Hraoui-Bloquet et al. 2002; Baha El Din S 2006; Amr and Disi 2011).

We equate species and subspecies as 'operational taxonomic units', or taxa. In the Levant most subspecies are well defined, the distinction between species and subspecies is unclear and some taxa have changed rank. The taxa, with indications in which area(s) each occurs, are listed in the Supplementary Material.

Our data on reptile distribution comprise locality records. Those in our survey area (Israel, western Golan Plateau, Palestinian Authority and Sinai Peninsula; Werner 1988) derived mainly from the National Collection at the Hebrew University of Jerusalem (HUJR) and partly from the Zoological Museum at Tel Aviv University (TAU-R). Most are backed by vouchers in these collections. Few are backed by photographs or our observations. Mapping was manual (Werner 1977). Locality records in Transjordan south of the Golan Plateau derived mainly from recent literature (Werner 1971; Amr et al. 1994; Disi 2002, 2011; Babocsay 2003; Amr and Disi 2011; Perry 2012).

Analysing the distribution data, we first ask how much the squamate faunas of southern arid Cis- and Transjordan differ from each other and how this is affected by the intervening 'Arava Valley. To achieve this, we used a log-linear model, based on a Poisson distribution. Our dependent variable was the number of species listed in each geographic region (Cis- and Transjordan and the 'Arava Valley). To be able to compare the probability of a species to be found in each region and in region-combinations, we used as the explanatory variable a set of three dummy variables that indicated the presence of the species in the three regions (i.e. overall each species could be categorized into one of seven explanatory groups, representing their appearance in only one region, in combinations of two regions and in all three regions). The statistical model tested whether the probability of the species to appear in the region-combinations deviated from a random distribution and assessed the relative deviation of each combination from randomness. Under the null hypothesis, the number of species observed in each combination of regions is the estimated number of species that should be classified to the specific region-combination, assuming that the observed data were a sample based on the Poisson distribution. Species are assumed to be under-represented or over-represented in a region-combination only if the observed data deviated significantly from the estimated value under the null hypothesis. As a control, we used a similar statistical model to test the probability of species to be listed in Cis- and Transjordan in the mesic north, where no barrier separates the two regions. Here our explanatory variables were composed of two sets of dummy variables and the species could be classified into three categories only (each of the regions separately or in both regions). We repeated all the analyses for the squamate fauna and for lizards and snakes separately.

We further tested the potential contribution of the 'Arava valley to the squamate fauna by testing for the probability of a species to be listed in the two regions. Here we employed a generalized linear model (GLM, with a binomial distribution and logit link) with the area of observation (north, where Cis- and Transjordan present a continuous geographical region, versus south, where the 'Arava valley separates the two), the squamate group (lizards or snakes) and the interactions between area and squamate group as explanatory variables. The statistical model tested whether there are fewer 
than expected shared species between Cis- and Transjordan as a function of the explanatory variables. All the statistical analyses were conducted using IBM SPSS Statistics 22.

\section{Results}

\section{Endemism to the 'Arava}

\section{Vertebrates}

One mammal, Gazella gazella acaciae Mendelssohn et al., 1997 (Figure 2), whose tiny population survives in the 'Arava, is clearly endemic to it (Clark and Frankenberg 2001; Shalmon 2002). No birds are endemic to the 'Arava.

Among reptiles, a clear endemic to the 'Arava is the snake Cerastes gasperettii mendelssohni Werner and Sivan (Viperidae). The Arabian-Jordanian C. gasperettii Leviton and Anderson, 1967 differs from the Saharan-Sinaitic Cerastes cerastes (Linnaeus 1758) in morphological characters, and so does the 'Arava's C. g. mendelssohni from C. g. gasperettii of sandy arid Jordan and Arabia (Werner et al. 1999).

No other reptile is known to be limited to the 'Arava but we preliminarily examined Acanthodactylus opheodurus Arnold, 1980 (Lacertidae). This psammophilous lizard ranges from Arabia and Jordan to the 'Arava (Werner et al. 2012). We counted the scales across the back at mid-body in 12 specimens and found 33-39 scales. Counts from Arabia were 29-36 scales (Salvador 1982) and 25-38 scales (Arnold 1986). The smaller number of scales in the 'Arava indicate that the population may differ.

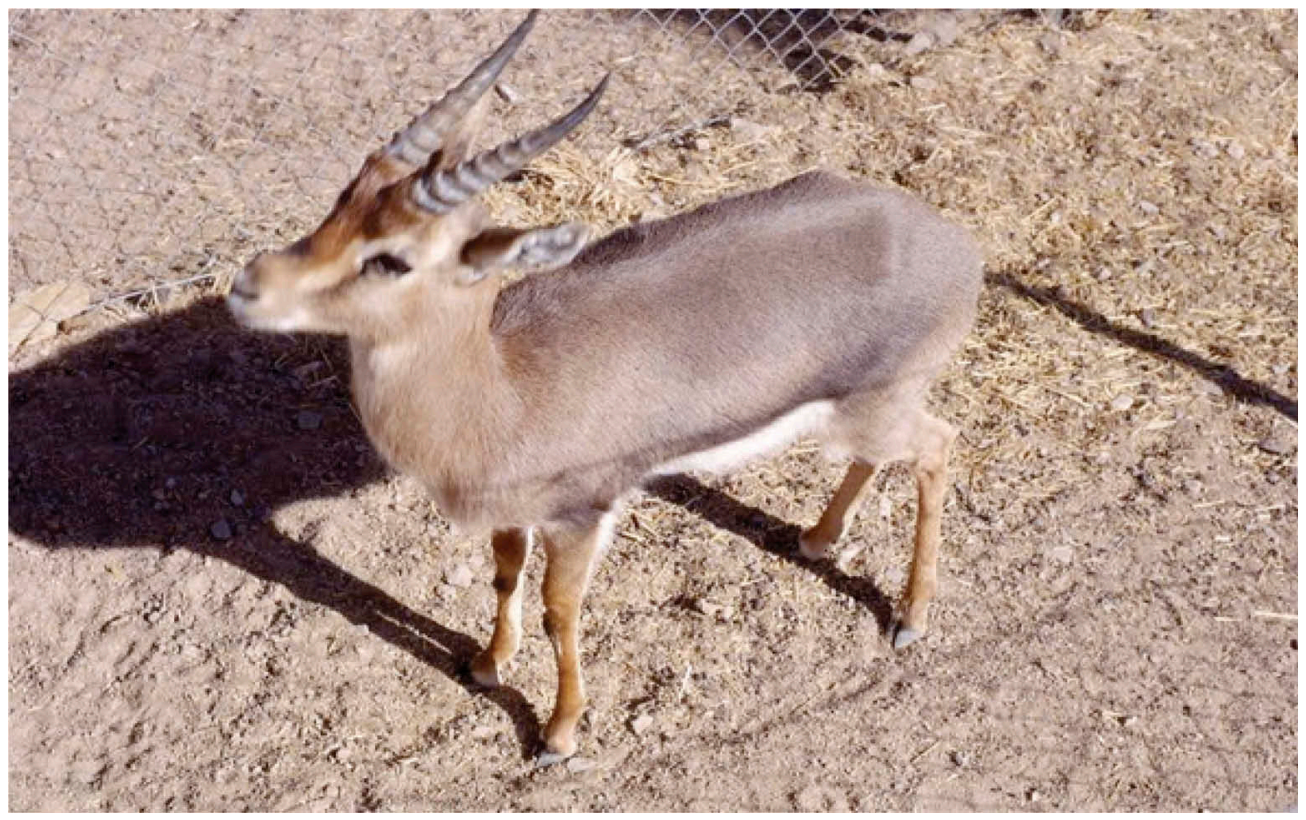

Figure 2. Young male Gazella gazella acaciae Mendelssohn et al. (1997) from the 'Arava Valley, photographed for identification in January 1964 in the then Elat Zoo, Israel, 33 years before the taxon was recognized and described (photo: YL \& N Werner). 
Furthermore Hoofien (1961) studied body proportions of Stenodactylus sthenodactylus Lichtenstein, 1823 from across Cisjordan. This Saharan gekkonid ranges eastwards to the 'Arava (Werner 1987a, 1987b). Hoofien (1961) concluded that 'Arava specimens averaged longer limbs and tail than all others, suggesting differentiation of the 'Arava population. Recently, genomic diversity in this species was found to differ between the Mediterranean coastal plain and the 'Arava (Peled et al. 2014), in accordance with this hypothesis.

Of the amphibians, the systematics of the only candidate, the green toad, currently Bufotes viridis (Laurenti 1768) or Bufotes variabilis (Pallas 1769), awaits revision. But a freshwater fish, Garra ghorensis Krupp, 1982 (Cyprinidae), is or was endemic to springs in the northernmost 'Arava - it is probably extinct (Goren and Ortal 1999; Goren 2002). In contrast, the endemic brackish-water Aphanius dispar richardsoni (Boulenger 1907) (Cyprinodontidae) probably survives in some of the small water bodies around the Dead Sea which it inhabited (Krupp and Schneider 1989).

\section{Invertebrates}

Arachnids. one scorpion, Buthacus yotvatensis Levy et al., 1973, is known only from the 'Arava sands; three records from elsewhere (Levy and Amitai 1980) appear unconvincing. The giant spider Cerbalus aravaensis (Levy 2007) (Sparassidae), is unknown outside the 'Arava sands. Likewise, five other spiders, Tmarus hazevensis (Levy 1973) (Thomisidae) (Levy 1985), Oxyopes elifaz Levy, 2007 (Oxyopidae), Singa ammophila Levy, 2007 and Neoscona lotan Levy, 2007 (Araneidae) and Ebo halophilus Levy, 1977 (Philodromidae), the latter occurring also in the Dead Sea basin (Levy 1977). Another spider is known only from the Dead Sea basin: Theridion vallisalinarum Levy \& Amitai, 1982 (Theridiidae) (Levy 1998).

Insects. two short-horned grasshoppers (Orthoptera: Acrididae) are known only from the 'Arava (and Dead Sea area): Sphingonotus hierichonicus Uvarov, 1923a and Hilethera hierochonica Uvarov, 1923b (Fishelson 1985). Likewise, five moths (Lepidopotera: Noctuidae) are unknown elsewhere (Kravchenko et al. 2007): Anarta (Hadula) engedina Hacker, 1998, Caradrina (Eremodrina) kravchenkoi Hacker, 2004, Caradrina (Paradrina) fibigeri Hacker, 2004, Odontelia daphnadeparisae Muller et al., 2007 and Polymixis aegyptiaca Kravchenko et al., 2005.

Two flies are endemic to the 'Arava: Apoclea parvula Theodor, 1980 and Apoclea inarticulata Theodor, 1980 (Asilidae) (Theodor 1980). A third is endemic to the Dead Sea area: Trupanea erigeroni Freidberg, 1974 (Tephritidae) (Freidberg and Kugler 1989). Two trichopterans are endemic to the Dead Sea basin: Stactobia margalitana Botosaneanu, 1974 and Ithytrichia dovporiana Botosaneanu, 1980 (Botosaneanu 1992).

Molluscs. No mollusc is endemic to the 'Arava.

\section{Plants}

Several of the 'Arava's and Dead Sea basin's plants, including dominant ones, are locally confined to these areas, so that within Cisjordan they occur nowhere else. But it is 
noteworthy that none are endemic here. Rather, generally they are Sudanian, Afrotropical (Shmida and Aronson 1986).

\section{Reptile distribution and the 'Arava's isolation}

\section{Distribution in the arid south - 'Arava and surroundings}

The pooled area of arid southern Cisjordan, the 'Arava and southern Transjordan harbours 70 squamate taxa. Within this area each taxon has one of seven distribution patterns: limited to one of the three areas, occurring in two areas (contiguous or not), or occurring in all three.

Table 1 and Figure 1 show that only 27 of the 70 taxa occur throughout the pooled area. The most species-rich distributions are Transjordan-only (19 taxa) and Cisjordanonly (10 taxa). Within the 'Arava there occur 36 taxa, but only one of these is restricted to the 'Arava.

Squamate distribution (lizards and snakes together) differed significantly from a random distribution $\left[x^{2}=35.61\right.$, with four degrees of freedoms (DF); $\left.p<0.001\right]$. The deviation can be attributed to the following discrepancies between the observed pattern (based on the listed species, Table 1) and the expected pattern under random distribution. There were fewer species detected only in the 'Arava valley than expected under random distribution ( $1 \%$ observed versus $4 \%$ expected, values are given as percentage of species out of the total number of species in the group); fewer species were detected in the combined regions of the 'Arava valley and Transjordan (7\% observed versus 15\% expected); and Cisjordan and Transjordan (7\% observed versus $25 \%$ expected). There were more species than expected detected in Transjordan (27\% observed versus $14 \%$ expected); Cisjordan (14\% observed versus $6 \%$ expected); and among the species expected to be found in all three regions (39\% observed versus $26 \%$ expected).

The deviation from random distribution of the listed species could also be observed for each of the squamate groups separately [Lizards: $x^{2}=24.67$ (4 DF); $p<0.001$; Snakes: $x^{2}=9.94$ (4 DF); $p=0.041$ ]. In both lizards and snakes, the deviation from random distribution was caused by fewer species detected in the combined regions of the 'Arava valley and Transjordan (Lizards: $9 \%$ observed versus

Table 1. Numbers of squamate taxa in southern Cisjordan, the 'Arava valley and southern Transjordan and their combinations. The expected number of species under a random distribution assumption is given in brackets.

\begin{tabular}{lccc}
\hline Area & Squamata & Lizards & Snakes \\
\hline Cisjordan & $10(4)$ & $9(4)$ & $1(2)$ \\
Cisjordan + 'Arava & $3(4)$ & $2(3)$ & $1(1)$ \\
'Arava & $1(3)$ & $0(2)$ & $1(2)$ \\
'Arava + Transjordan & $5(11)$ & $4(6)$ & $1(3)$ \\
Transjordan & $19(11)$ & $16(10)$ & $3(1)$ \\
All three areas & $27(19)$ & $12(8)$ & $15(11)$ \\
Cisjordan + Transjordan & $5(18)$ & $4(14)$ & $1(3)$ \\
Total in the south & 70 & 47 & 23 \\
Cisjordan total & 45 & 27 & 18 \\
'Arava total & 36 & 18 & 18 \\
Transjordan total & 56 & 36 & 20 \\
\hline
\end{tabular}


Table 2. Numbers of squamate taxa in northern Cisjordan and northern Transjordan and their combination.

\begin{tabular}{lccc}
\hline Area & Squamata & Lizards & Snakes \\
\hline Cisjordan & 6 & 2 & 4 \\
Cisjordan + Transjordan & 35 & 15 & 20 \\
Transjordan & 14 & 4 & 10 \\
& 55 & 21 & 34 \\
Total in the north & 41 & 17 & 24 \\
Cisjordan total & 49 & 19 & 30 \\
Transjordan total & & & \\
\hline
\end{tabular}

13\% expected; Snakes: $4 \%$ observed versus $15 \%$ expected) and in the combined region of Cis- and Transjordan (Lizards: 9\% observed versus 27\% expected; Snakes: $4 \%$ observed versus $15 \%$ expected). In contrast, there were more species than expected by random listed only in Transjordan (Lizards: $34 \%$ observed versus $20 \%$ expected; Snakes: $13 \%$ observed versus $4 \%$ expected) and among the species found in all three regions (Lizards: $26 \%$ observed versus 17\% expected; Snakes: $65 \%$ observed versus $53 \%$ expected). Lizards and snakes did not follow the same distribution pattern in all the region-combinations: No species of lizard was listed only in the 'Arava and $19 \%$ of the species were observed in Cisjordan (under random distribution only $8 \%$ were expected). The number of snake species found in the 'Arava valley and in Cisjordan was lower than expected under random distribution (4\% observed versus $8 \%$ expected).

\section{Distribution in the mesic north (a control)}

The pooled area of mesic northern Cis- and Transjordan harbours, as Table 2 and Figure 1 show, 55 squamate taxa. This number excludes four taxa known only from the Mount Hermon heights. It does include some taxa considered typical of the Mount Hermon heights but reported also from Galilee or the Golan, because of the difficulty in discriminating these from those inhabiting the Galilee, Golan or both and occurring also on Mount Hermon (Hurvitz et al. 1980; Werner and Avital 1980; Werner 1990b; Sivan and Werner 1992; Nathan and Werner 1999).

Squamate distribution (Table 2 ) did not significantly differ from a random distribution $\left[\mathrm{X}^{2}=2.30\right.$ (1 DF); $\left.p=0.129\right]$. Differences between observed and expected distributions were small. This remained true after splitting the data between lizards $\left[x^{2}=0.52\right.$ (1 DF), $p=0.471]$ and snakes [ $\mathrm{X}^{2}=1.89$ ( $\left.\left.1 \mathrm{DF}\right), p=0.169\right]$. In both cases the distribution was similar between the observed and expected, with the majority of species found in both Cis- and Transjordan.

\section{Comparison between the southern and the northern regions}

Our analysis showed that the probability of squamate species to be found in both Cisand Transjordan was not significantly affected by the two explanatory variables separately [region (north or south): $x^{2}=1.87$ (1 DF), $p=0.171$; species (lizards or snakes): $x^{2}=1.32$ ( 1 DF), $p=0.251$ ]. However, the model showed a significant interaction between the two explanatory variables $\left[x^{2}=6.40\right.$ (1 DF), $\left.p=0.011\right]$. The significant interaction resulted from a significantly lower probability of a species to belong to the 


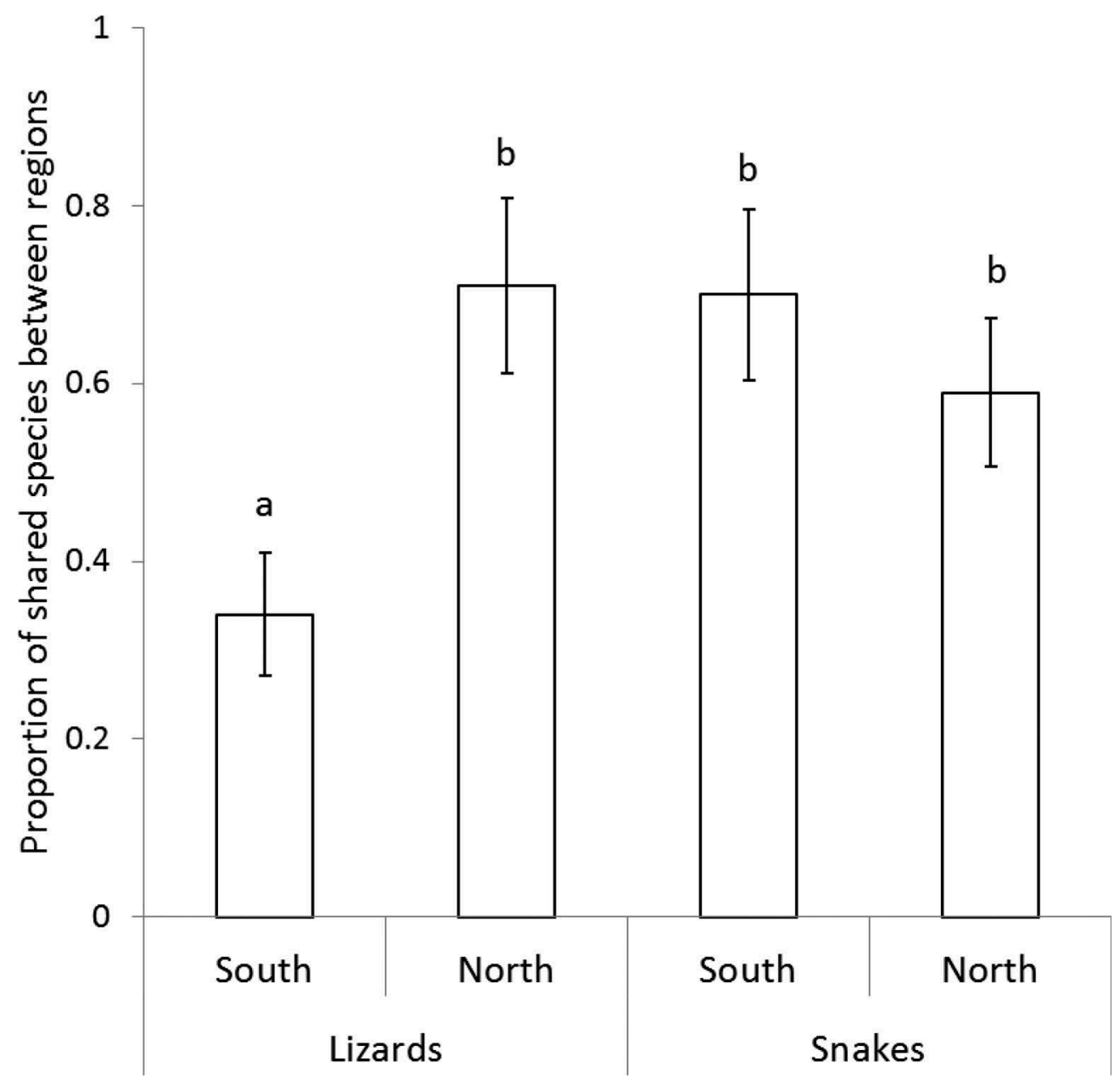

Figure 3. The estimated proportions ( $\pm \mathrm{SE}$ ) of shared species (species occurring in both Israel and Jordan) among all the regions in the north and south studied areas. Groups with similar letters are not significantly different from each other.

lizards in the southern region, where the 'Arava valley is located, relative to the other groups (Figure 3).

\section{Discussion}

\section{General}

Our census of potential endemics found that the 'Arava valley and the adjacent Dead Sea basin contain considerable endemism, at least ostensibly, in many zoo-taxonomic groups. Our survey of reptile distribution across the 'Arava found fewer species common to Cis- and Transjordan than in the north, implying that the 'Arava valley, while serving as a meeting point for species of both geographic regions, serves also as a filter that limits the ability of species to cross between the adjacent regions. This finding, 
combined with other indications from the literature and specific species observations, suggests that the depression is faunally partly isolated, at least as exemplified by the squamates. Therefore the endemism apparent in it seems credible, at least as a general phenomenon. This in itself indicates that the area merits conservation. Nevertheless some aspects require consideration.

\section{Methodology}

Arguments based on presence-absence must overcome the difficulty of proving the absence of something. This difficulty is much greater for animals than for plants. Accordingly many faunal reports lack data on the search effort and so present groundless conclusions. Herein some of the absence reports, especially for the reptiles, are supported by finding allopatric related taxa that are similar in ecological behaviour and collectability. All other absence reports are supported, as above, by the area's relative isolation. This argument and method promote 'possible endemics' to 'highly probable endemics' and enable the definition of 'terrestrial islands' for conservation.

It may be that this argument could gain support from the application of contemporary methodologies of biogeography and phylogeography. However, biogeography concludes patterns (spatial and dynamic) from collective distribution data; it does not affect the statistical validity of an actual set of geographical distributions at a given location and time. Phylogeography might 'make assurance doubly sure' for the systematic distinction of the taxa involved, although mainly if whole-genome data were available (Werner 2010). But would require funding, whereas this project is about achieving conservation without funding.

\section{Endemism to the 'Arava}

As exemplified by the flora, where it is easier to verify endemism, the endemism rate among the biota of Cisjordan is low (Shmida 1984; Shmida and Aronson 1986). This is expected from the aforementioned biogeographic situation - most taxa have most of their distribution outside the study area. Nevertheless we identified 13 zootaxa endemic strictly to the 'Arava plus two lizards hypothesized to share this status, four endemic to the combined 'Arava and Dead Sea basin and six endemic to the Dead Sea basin. Although future research may disqualify some of the invertebrate data, the 'Arava depression clearly has some animal endemism.

Additionally, the 'Arava's unique environment may potentially provide a last refuge for taxa that are declining elsewhere. A notable example (on the local scale), is the Nubian nightjar Caprimulgus nubicus, once widespread in Israel and now reduced to the 'Arava (Perlman 2008).

The absence of endemic plants is unexpected. Usually the rate of plant endemism resembles that of animals, and in Mediterranean and arid climates greatly exceeds it (Myers et al. 2000). Two hypotheses merit investigation: that locally animal systematics is more 'splitting' than plant systematics, and that concerning some abiotic variable(s) animals are more demanding than plants. 


\section{Isolation of the 'Arava}

Although not a barrier like the Dead Sea, the 'Arava does seem to be a hurdle between west and east. For reptiles from either direction the hurdle may act at either of its two boundaries (see Supplementary Material). The taxon may fail to penetrate into the 'Arava (e.g. from Cisjordan Stenodactylus petrii Anderson 1896; from Transjordan Stenodactylus grandiceps Haas 1952) or the taxon does invade the 'Arava but fails to spread out to the other side (e.g. from Cisjordan Sphenops sepsoides Audouin 1827; from Transjordan Stenodactylus doriae Blanford 1874).

For lack of proven data we cannot fully identify the obstacles to taxon dispersal but soil type seems to be influential. Sand, with its semi-fluid state, imposes morphological adaptations on sand-dwelling animals. Therefore for the distribution of non-volant species, separate sand areas function as islands (Werner 1987a). The sandy component of the 'Arava must play an unquantified but major role in its isolation.

The fact that in the southern deserts relatively twice as many snakes as lizards occur in both Cis- and Transjordan (Table 1), unlike in the north (Table 2), may be explained by two relevant differences between these groups. First, lizards as a group are mostly diurnal and susceptible to climatic differences such as those encountered across the 'Arava. In contrast, the thermal requirements of snakes are less precise (Shacham et al. 2009) and moreover many can dodge the day-time heat through nocturnal activity enabled by their eye structure (Werner 2016). Second, the cliffs bounding the 'Arava on its east are probably a hurdle for many lizards but not for snakes, considering their morphology and locomotion techniques (Werner 2016). However, not enough is known about the species involved to solidly explain the distributions of all.

\section{Parallelism to the 'Arava}

Much endemism occurs in the biodiversity hotspots on mountain peaks, as due to the altitude difference these are climatically isolated like islands (Allee and Schmidt 1951; Levin et al. 2007). Could a similar effect accrue from the opposite altitude difference of depressions, such as the 'Arava and Dead Sea depression or the Turpan depression of China? This question remains to be discussed elsewhere.

\section{Implications for conservation}

In the case of our model site, the 'Arava depression, our concern for its conservation is intensified by the precedent of the more northern endemism pocket, the Hula Lake (approx. $5 \times 4 \mathrm{~km}$ ) and surrounding marshes, within the northern part of the SyrioAfrican Rift Valley (approx. $20 \mathrm{~km}$ north of the Sea of Galilee). The lake and marshes were drained in the 1950s to reclaim land and fight malaria (Karmon 1960). The dammed-in nature reserve that was erected (approx. $1.2 \times 1.2 \mathrm{~km}$ ), retains only some of the endemic animals (there were no endemic plants) that had inhabited the lake (Dimentman et al. 1992; Grillitsch and Werner 2009). Three endemic fish species have disappeared (Goren and Ortal 1999). In recent decades a regret-driven enterprise of re-flooding part of the area (Dimentman et al. 2000) has partly restored the station for migrating water fowl (Shy et al. 1998). 
Previously the 'Arava was regarded by Israeli biologists as an outpost of Arabian ecosystems with an Afro-tropical invasion (Werner 1987a, 1990a), providing access within the country to biota that would otherwise remain 'exotic'. Therefore local biologists wished its conservation. But as shown here, the 'Arava is semi-isolated. It seems to function as a barrier or hurdle between the south Cisjordanian desert on its west and the south Transjordanian desert on its east. Moreover, its fauna includes indications of endemism (neo-endemism; Zohary 1973), presumably due to this isolation. This means that loss of the Araba biota would not be a mere national loss of access to species; rather, it would be a global loss of biodiversity.

Recently Israel's daily, Haaretz, reviewed the numerous development programmes for the 'Arava that constitute threats to the fauna (Rinat 2014). The major ones are expanding the agriculture, a debatably located railway, and establishing a major airport. In terms of the IUCN classification of threats (Salafsky et al. 2008) these respectively represent \# 2.1, 4.1, and $1.1+4.1+4.4$. However, the classification does not sufficiently represent the actual cropping, removal, of an airport-sized area from a circumscribed terrestrial island.

We hold that the low species richness of arid landscapes does not annul their value for conservation (Levin and Shmida 2007). The 'Arava sensu lato warrants conservation for several reasons, beyond being the deepest terrestrial depression on earth.

(1) Its environment, which beyond harbouring Arabian and Sudanian plants and animals promotes endemism, at least of animals.

(2) Its offering a refuge to taxa that have vanished from surrounding deserts.

(3) Its ecology is threatened, especially through being very accessible.

Another asset of the 'Arava is its hosting much research and education. In situ institutes include the 'Arava Institute (Shanas et al. 2006; Kalman 2013), bird study centres (Leshem et al. 2009) at Hazeva (Zahavi 1990; Katsir 1995), Lotan and Elat (Yosef and Tryjanowski 2009; Yosef and Markovets 2009) and the Israel Nature and Parks Authority's Hai-Bar acclimation station. Many student theses investigate the 'Arava (e.g. Bouskila 1984, 1986; Shani 1990; Katsir 1995; Bogin 1997, 1999). The diverse biological investigation of the 'Arava extends also to palaeontology (Rabinovich et al. 2015). Visiting researchers gain logistic support from the Society for the Protection of Nature in Israel's field schools at En Gedi, Hazeva and Elat. Moreover, its proximity to central research institutions facilitates exploiting the 'Arava's unique opportunity to investigate the biogeographic isolation hypothetically altitude-driven in depressions as in mountains.

\section{Acknowledgements}

For information and literature (field in parentheses) we thank the late Avinoam Danin (plants), Eliezer Frankenberg (mammals, conservation), Uwe Fritz (turtles), David Furth (insects), Efrat Gavish-Regev (arachnids), Menachem Goren and Fareed Krupp (fish), Joseph Heller (mollusks), Vasiliy Kravchenko (moths), Shai Meiri (biogeography), Nir Sapir (birds), Avi Shmida (plants), Dany Simon (invertebrates), Amir Weinstein (insects), Yoram Yom-Tov (mammals), and Jotham ZifferBerger (plants). For patient drafting of Figure 1 we thank Zehava Cohen. 


\section{Disclosure statement}

No potential conflict of interest was reported by the authors.

\section{References}

Allee WC, Schmidt KP. 1951. Ecological animal geography. 2nd ed. London: Chapman \& Hall.

Amitai P, Bouskila A. 2001. Guide to reptiles and amphibians in Israel. Jerusalem: Keter (In Hebrew). Amr ZS, Al-Oran RM, Disi AM. 1994. Reptiles of southern Jordan. Snake. 26:41-49.

Amr ZS, Disi AM. 2011. Systematics, distribution and ecology of the snakes of Jordan. Vert Zool. 61:179-266.

Anderson J. 1896. A Contribution to the Herpetology of Arabia, with a preliminary list of the reptiles and batrachians of Egypt. London: Porter.

Anderson SC. 1968. The Cambridge history of Iran vol.1, The land of Iran (ed. WB Fisher). Cambridge: Cambridge University Press. Zoogeographic analysis of the lizard fauna of Iran; $\mathrm{p}$. 305-371.

Arnold EN. 1980. The scientific results of the Oman flora and fauna survey 1977 (Dhofar). The reptiles and amphibians of Dhofar, southern Arabia. J Oman Stud Spec Rep. 2:273-332.

Arnold EN. 1986. A key and annotated check list to the lizards and amphisbaenians of Arabia. Fauna of Saudi Arabia. 8:385-435.

Ashton KG, Feldman CR. 2003. Bergmann's rule in non-avian reptiles: turtles follow it, lizards and snakes reverse it. Evolution. 57:1151-1163.

Atlas of Israel. 1985. Tel Aviv: Survey of Israel \& London: Collier Macmillan.

Audouin JV. 1827. Explication sommaire des planches de reptiles (supplément) ... offrant un exposé des caractères naturels des genres, avec la distinction des espèces. In: De Savigny MJCL, editor. Description d'Égypte. Vol. I. Historie Naturelle. Paris: Imprimerie impériale/ Imprimerie royale.

Babocsay G. 2003. Geographic variation in Echis coloratus (Viperidae, Ophidia) in the Levant with the description of a new subspecies. Zool Middle East. 29:13-32.

Babocsay G, Shacham B, Werner YL. 2006. Importance of collections in describing biodiversity: four new reptiles and their conservational and medical implications. Magyar Biologiai Társaság. Vándorgyülés. 26:193-203 (In Hungarian with English abstract).

Baha El Din S. 2006. A guide to the reptiles and amphibians of Egypt. Cairo: The American University in Cairo Press.

Baha El Din SM. 2007. A new lizard of the Acanthodactylus scutellatus group (Squamata: lacertidae) from Egypt. Zool Middle East. 40:21-32.

Blanford WT. 1874. Descriptions of new lizards from Persia and Baluchistàn. Ann Mag Nat Hist. 13:453-455.

Bogin Y. 1997. The effects of predators on the burrowing behavior of Stenodactylus doriae (Reptilia: gekkonidae). Abstracts, Third World Congress of Herpetology, 2-10 August 1997, Prague, p. 24.

Bogin Y. 1999. Effects of environmental factors, predator and pests (burrow destroyers and invaders) on the burrowing behaviour of Stenodactylus doriae [MSc Thesis, Environmental Biology]. Jerusalem: The Hebrew University of Jerusalem. Hebrew.

Böhm M, Collen B, Baillie JEM, Bowles P, Chanson J, Cox N, Hammerson G, Hoffmann M, Livingstone SR, Ram M, et al. 2013. The conservation status of the world's reptiles. Biol Cons. 157:372-385.

Botosaneanu L. 1974. Quatre nouvelles espèces palestiniennes de Trichoptères. Isr J Ent. 9:159174.

Botosaneanu L. 1980. Quelques Trichoptères nouveaux du Jourdain (Trichoptera, Hydropsychidae). Bull zool Mus Amsterdam. 7:73-80.

Botosaneanu L. 1992. Fauna Palaestina: trichoptera of the Levant. Jerusalem: The Israel Academy of Sciences and Humanities.

Boulenger GA. 1907. Zoology of Egypt. The fishes of the Nile. 2 vols. London: H. Rees. 
Bouskila A 1984. Habitat selection, especially burrow site location, of Uromastyx aegyptia in the Hazeva region [MSc Thesis, Zoology]. Jerusalem: The Hebrew University of Jerusalem. Hebrew.

Bouskila A. 1986. Habitat selection in the desert lizard Uromastyx aegyptius and its relation to the autecological hypothesis. In: Dubinsky Z, Steinberger $Y$, editors. Environmental quality and ecosystem stability. Volume 3/A \& 3/B. Proceedings of the 3rd International Conference of the Israel Society for Ecology \& Environmental Quality Sciences. Ramat-Gan, Israel: Bar-Illan University Press.

Brattstrom BH. 1965. Body temperatures of reptiles. Am Mus Novit. 73:376-422.

Clark B, Frankenberg E. 2001. Chapter 19. Israel (including West Bank and Gaza). In: Mallon DP, Kingswood SC, editors. Antelopes. Part 4: north Africa, the Middle East, and Asia. Gland: IUCN.

Collins JT, Collins SL, Taggart TW. 2010. Amphibians, reptiles, and turtles in Kansas Eagle Mountain. Utah: Eagle Mountain Publishing.

Danin A. 2013. Near East ecosystems, plant diversity. In: Levin SA, editor. Encyclopedia of biodiversity. Vol. 5, 2nd ed. Waltham, MA: Academic Press.

Danin A, Plitmann U. 1987. Revision of the plant-geographical territories of Israel and Sinai. Plant Syst Evol. 156:43-53.

Dimentman C, Bromley HJ, Por FD. 1992. Lake Hula: reconstruction of the fauna and hydrobiology of a lost lake. Jerusalem: The Israel Academy of Sciences and Humanities.

Dimentman C, Bromley HJ, Por FD. 2000. Reflooding the old swamps of Lake Hula (Israel) emphasis on zooplankton dynamics. Verh Internat Ver Limnol. 27:3044-3047.

Disi AM. 1996. A contribution to the knowledge of the herpetofauna of Jordan. VI. The Jordanian herpetofauna as a zoogeographic indicator. Herpetozoa. 9:71-81.

Disi AM. 2002. Jordan country study on biological diversity: the herpetofauna of Jordan. Amman: The General Corporation for the Environment Protection.

Disi AM. 2011. Review of the lizard fauna of Jordan (Reptilia: sauria). Zool Middle East, Biodiversity Conservation in the Arabian Peninsula. 54:89-102. doi:10.1080/09397140.2011.10648900

Fishelson L. 1985. Fauna Palaestina: orthoptera: acridoidea. Jerusalem: The Israel Academy of Sciences and Humanities.

Freidberg A. 1974. Descriptions of new Tephritidae from Israel. I J Ent Soc Sth Afr. 37:49-62.

Freidberg A, Kugler J. 1989. Fauna Palaestina: insecta IV- Diptera: Tephritidae. Jerusalem: The Israel Academy of Sciences and Humanities.

Gans C. 1970. How snakes move. Sci Am. 222:82-96.

Goren M. 2002. Fishes. In: Dolev A, Perevolotsky A, editors. Endangered species in Israel. Red list of threatened animals: vertebrates. Jerusalem: Nature and Parks Authority \& the Society for the Protection of Nature. Hebrew.

Goren M, Ortal R. 1999. Biogeography, diversity and conservation of the inland water fish communities in Israel. Biol Conserv. 89:1-9.

Grillitsch H, Werner YL. 2009. The southern limit of Natrix natrix natrix in the Levant - a detective story. Herpetozoa. 22:65-74.

Haas G. 1952. Two collections of reptiles from Iraq, with descriptions of two new forms. Copeia. 1952:20-22.

Hacker H. 1998. Revision der Gattungen Hadula Staudinger, 1889 (=Discestra Hampson, 1905, =Aglossestra Hampson, 1905; Cardiestra Boursin, 1963), Anartomorpha Alpherasky, 1892, Trichanarta Hampson,1895, Anarta Ochsenheimer, 1816 und Cardetia Hampson, 1905 mit Beschreibung einer neuen Gattung Hadumorpha gen. n. (Lepidoptera, Noctuidae). Esperiana. 6:577-911.

Hacker H. 2004. Revision of the genus Caradrina Ochsenheimer, 1816, with notes on other genera of the tribus Caradrini (Lepidoptera, Noctuidae). Esperiana. 10:1-690, 722-775.

Hoofien JH 1961. Note on variations in somatic proportions found in different populations of Stenodactylus sthenodactylus in Cis-Jordania (Unpublished manuscript).

Hraoui-Bloquet S, Sadek RA, Sindaco R, Venchi A. 2002. The herpetofauna of Lebanon: new data on distribution. Zool Middle East. 27:35-46.

Huey RB, Pianka ER, Schoener TW, editors. 1983. Lizard ecology, studies of a model organism. Cambridge, MA: Cambridge University Press. 
Hurvitz E, Lev Ari Y, Shluter P, Geller S, Shmida A. 1980. Check-List of vertebrates of Mt. Hermon. In: Shmida A, Livne M, editors. Mt. Hermon nature and landscape. Hakibbutz Hameuchad, with the Society for Protection of Nature, Usishkin House and the Nature Reserves Authority. Hebrew.

Kalman M. 2013 Feb. In the Israeli desert, a modest effort to build an environment for peace. The Chronicle of Higher Education.

Kark S, Warburg I, Werner YL. 1997. Polymorphism in the snake Psammophis schokari on both sides of the desert edge in Israel and Sinai. J Arid Env. 37:513-527.

Karmon Y. 1960. The drainage of the Huleh swamps. Geogr Rev. 50:169-193.

Katsir Z. 1995. The meaning of the 'variations' in the babbler 'shout': A musical-ethological approach. Behav Proc. 34:213-232.

Kravchenko VD, Fibiger M, Hausmann A, Müller GC. 2007. Noctuidae. In: Müller GC, Kravchenko D, Hausmann A, Speidel W, Mooser J, Witt TG, editors. Lepidoptera of Israel. Vol. 2. Pensoft Series Faunistica. 63. p. 1-400.

Kravchenko VD, Fibiger M, Mooser J, Müller GC. 2005. The Polymixis Hübner, [1820] genus-group of Israel, with description of one new species and one new subspecies (Lepidoptera, Noctuidae). Sociedad Hispano-Luso-Americana de Lepidopterologia (SHILAP). 33:487-502.

Krupp F. 1982. Garra tibanica ghorensis subsp. nov. (Pisces: cyprinidae), an African ekement in the cyprinid fauna of the Levant. Hydrobiologia. 88:319-324.

Krupp F, Schneider W. 1989. The fishes of the Jordan River drainage basin and Azraq Oasis. Fauna of Saudi Arabia. 10:347-416.

Laurenti JN. 1768. Specimen medicum, exhibens Synopsin Reptilium. Viennae: Thomae \& Trattnern. 27: Plate 1: Fig. 1. (Reprinted 1966 by A. Asher).

Leshem Y, Alon D, Engel (Jucha) JAY, Idelman A, Haklai R. 2009. The development of a national network of bird watching centers in Israel and their contribution to the environment, tourism, education and research. Environmental policy center publications. (Hebrew with Arabic and English summaries). Available from: http://bit.ly/lnkkRWZ.

Levin M, Shmida A, Levanoni O, Tamari H, Kark S. 2007. Predicting mountain plant richness and rarity from space using satellite-derived vegetation indices. Divers. Distrib. 13:692-703.

Levin N, Shmida A. 2007. Determining conservation hotspots across biogeographic regions using rainfall belts: Israel as a case study. Isr J Ecol Evol. 53:33-58.

Leviton AE, Anderson SC. 1967. Survey of the reptiles of the Sheikdom of Abu Dhabi, Arabian Peninsula. Part II. Systematic account of the collection of reptiles made in the Sheikdom of Abu Daby by John Gasperetti. Proc Calif Acad Sci. 39:157-192.

Levy G. 1973. Crab-spiders of six genera from Israel (Araneae: Thomisidae). Isr J Zool. 22:107-141. Levy G. 1977. The philodromid spiders of Israel (Araneae: Philodromidae). Isr J Zool. 26:193-229.

Levy G. 1985. Fauna Palaestina: archnida II: araneae: Thomisidae. Jerusalem: The Israel Academy of Sciences and Humanities.

Levy G. 1998. Fauna Palaestina: Arachnida III: Araneae: Theridiidae. Jerusalem: The Israel Academy of Sciences and Humanities.

Levy G. 2007. Calommata (Atypidae) and new spider species (Araneae) from Israel. Zootaxa. 1551:1-30.

Levy G, Amitai P. 1980. Fauna Palaestina: Arachnida I: Scorpiones. Jerusalem: The Israel Academy of Sciences and Humanities.

Levy G, Amitai P. 1982. The comb-footed spider genera Theridion, Achaearanea and Anelosimus of Israel (Araneae: Theridiidae). J Zool Lond. 196:81-131.

Levy G, Amitai P, Shulov A. 1973. New scorpions from Israel, Jordan and Arabia. Zool J Linn Soc Lond. 52:113-140.

Lichtenstein MHC. 1823. Verzeichniss der Doubletten des zoologischen Museums der Königlichen Universität zu Berlin nebst Beschreibung vieler bisher unbekannter Arten von Säugethieren, Vögeln, Amphibien und Fischen. Berlin: T. Trautwein.

Linnaeus C. 1758. Systema naturæ per regna tria naturæ, secundum classes, ordines, genera, species, cum characteribus, differentiis, synonymis, locis. Tomus I, reformata. 10th ed. Stockholm: Laurentii Salvii. 
Mandelik Y, Roll U, Fleischer A. 2010. Cost-efficiency of biodiversity indicators for Mediterranean ecosystems and the effects of socio-economic factors. J Appl Ecol. 47:1179-1188.

Mendelssohn H, Groves CP, Shalmon B. 1997. A new subspecies of Gazella gazella from the Southern Negev. Isr J Zool. 43:209-215.

Milstead WW, editor. 1967. Lizard ecology: a symposium. Columbia, Missouri: University of Missouri Press.

Muller GC, Kravchenko VD, Ronkay L, Speidel W, Witt T, Mooser J, Junnila A, Zilli A. 2007. A new species of Odontelia Hampson, 1905 from Israel and its ecology (Lepidoptera: Noctuidae, Hadeninae). Entomologische Zeitschrift. 117:243-247.

Myers N, Mittermeier RA, Mittermeier CG, Da Fonseca GAB, Kent J. 2000. Biodiversity hotspots for conservation priorities. Nature. 403:853-858.

Nathan R, Werner YL. 1999. Reptiles and breeding birds on Mt. Hermon: patterns of altitudinal distribution and species richness. Isr J Zool. 45:1-33.

Orme CDL, Davies RG, Burgess M, Eigenbrod F, Pickup N, Olson VA, Webster AJ, Ding TS, Rasmussen PC, Ridgely RS, et al. 2005. Global hotspots of species richness are not congruent with endemism or threat. Nature. 436:1016-1019.

Pallas. 1769. Spicileg. Zool. 7:1 Plate 6: Fig. 3-4.

Peled E, Ben-Shlomo R, Shanas U. 2014. Specialists may thrive in small habitats: the case of high genetic diversity within a confined gecko population. J. Zool. London. 293:100-107.

Perlman Y. 2008. The natural history of the Nubian nightjar Caprimulgus nubicus in Israel. Sandgrouse. 30:117-124.

Perry G. 2012. On the appropriate names for snakes usually identified as Coluber rhodorachis (Jan, 1865 ) or why ecologists should approach the forest of taxonomy with great care. IRCF Rep Amph Cons Nat Hist. 19:90-100.

Quinn JF, Harrison SP. 1988. Effects of habitat fragmentation and isolation on species richness: evidence from biogeographic patterns. Oecologia. 75:132-140.

Rabinovich R, Hanan H, Schudack M, Schudack U, Ashckenazi-Polivoda S, Rogolsky G 2015. A late Cretaceous elasmosaurid of the Tethys Sea margins (southern Negev, Israel), and its palaeogeographic reconstruction. Netherl J Geosci. 94. doi:10.1017/njg.2014.26

Reilly SM, McBrayer LB, Miles DB, editors. 2007. Lizard ecology. Cambridge: Cambridge University Press.

Rinat Z 2014. Weeping 'Arava. Haaretz 16 January 2014: 3. Hebrew.

Roll U, Stone L, Grenyer R, Meiri S. 2011. Not so holy after all. Isr J Ecol Evol. 57:193-204.

Roll U, Stone L, Meiri S. 2009. Hot-spot facts and artifacts-questioning Israel's great biodiversity. Isr J Ecol Evol. 55:263-279.

Salafsky N, Salzer D, Stattersfield AJ, Hilton-Taylor C, Neugarten R, Butchart SHM, Collen B, Cox N, Master LL, O'Connor S, Wilkie D. 2008. A standard lexicon for biodiversity conservation: unified classifications of threats and actions. Cons Biol. 22:897-911.

Salvador A. 1982. A revision of the lizards of the genus Acanthodactylus (Sauria: lacertidae). Bonn Zool Monogr. 16:1-167.

Shacham B, Federman R, Lahav-Ginott S, Werner YL. 2009. Snakes outrace lizards: the northward penetration of desert reptiles along the Jordan Valley (Israel). Isr J Ecol Evol. 55:173.

Shacham B, Federman R, Lahav-Ginott S, Werner YL. 2015. The northward extension of reptiles in the northern hemisphere, with the Jordan Valley (Israel) as a model: snakes outrace lizards. J Nat Hist. 50:1017-1033.

Shalmon B. 2002. Class Mammalia. In: Dolev A, Perevolotsky A, editors. Red list of threatened animals: vertebrates. Jerusalem: Nature and Parks Authority \& the Society for the Protection of Nature. Hebrew; p. 203-275.

Shanas U, Abu Galyun Y, Alshamlih M, Cnaani J, Guscio DU, Khoury F, Mittlera S, Nassar K, Shapira I, Simon $D$, et al. 2006. Reptile diversity and rodent community structure across a political border. Biol Cons. 132:292-299.

Shani E 1990. The feeding ecology of adult Cerastes cerastes gaperettii. Observations in temperature rooms, enclosure and the field [MSc Thesis, Zoology]. Jerusalem: The Hebrew University of Jerusalem. Hebrew. 
Shmida A. 1984. Endemism in the flora of Israel. Botanische Jahrbücher für Systematik, Pflanzengeschichte und Pflanzengeographie. Leipzig. 104:537-567.

Shmida A, Aronson J. 1986. Sudanian elements in the flora of Israel. Ann Missouri Bot Gard. 73:128.

Shy E, Beckerman S, Oron T, Frankenberg E. 1998. Repopulation and colonization by birds in the Agmon wetland, Israel. Wetlands Ecol Manag. 6:159-167.

Sivan N, Werner YL. 1992. Survey of the reptiles of the Golan Plateau and Mt. Hermon, Israel. Isr J Zool. 37:193-211.

Sivan N, Werner YL. 2003. Revision of the Middle-Eastern dwarf- snakes commonly assigned to Eirenis coronella (Colubridae). Zool Middle East. 28:39-59.

Theodor O. 1980. Fauna Palaestina: insecta II- Diptera: Asilidae. Jerusalem: The Israel Academy of Sciences and Humanities.

Townsend TM, Larson A, Louis E, Macey JR. 2004. Molecular Phylogenetics of Squamata: the position of snakes, amphisbaenians, and dibamids, and the root of the squamate tree. Syst Biol. 53:735-757.

Uvarov BP. 1923a. in: Buxton PA, Uvarov BP. A contribution to our knowledge of Orthoptera in Palestine. Bull Soc R Ent Égypte. 1923:167-214.

Uvarov BP 1923b. Entomologist's mon. mag. 9. 83.

Vitt LJ, Pianka ER, editors. 1994. Lizard ecology: historical and experimental perspectives. Princeton, NJ: Princeton University Press.

Werner YL. 1968. Distribution of the Saharan Sphenops sepsoides (Reptilia: Scincidae) in Israel and Jordan. Herpetologica. 24:238-242.

Werner YL. 1971. Lizards and snakes from Transjordan, recently acquired by the British Museum (Natural History). Bull Br Mus Nat Hist (Zool). 21:213-256.

Werner YL. 1977. Manual mapping of locality records - an efficient method. J Biogeogr. 4:51-53.

Werner YL. 1982. Herpetofaunal survey of the Sinai Peninsula (1967-1977), with emphasis on the Saharan sand community. In: Scott Jr NJ, editor. Herpetological communities: a symposium of the Society for the Study of Amphibians and Reptiles and the Herpetologists' League, August 1977 U.S. Fish and Wildlife Service. Wildlife Research Report. 13; p. 153-161.

Werner YL. 1987a. Ecological zoogeography of the Saharo-Arabian, Saharan and Arabian reptiles in the desert sands of Israel. In: Krupp F, Schneider W, Kinzelbach R, editors. Symposium on the Fauna and Zoogeography of the Middle East. Tuebingen Atlas des Vorderen Orients, Beiheft 28A. Wiesbaden: Reichert Verlag; p. 272-295.

Werner YL. 1987b. Gekkonid lizards from five zoogeographic quarters meet in Israel. Bull Philadelphia Herpetol Soc. 31:20-33.

Werner YL. 1988. Herpetofaunal survey of Israel (1950-1985), with comments on Sinai and Jordan and on zoogeographical heterogeneity. In: Yom-Tov Y, Tchernov E, editors. The zoogeography of Israel. Dordrecht, Netherlands: Dr. W. Junk Publishers; p. 355-388.

Werner YL. 1990a. Ecological biogeography of reptiles in the sand deserts of Israel. Hardun J Isr Herpetol Info Cent. 5:33-55. (Hebrew, English abstract p. 81.).

Werner YL 1990b. The zoogeographical relations of the reptiles that occur on the Hermon and are absent from Israel. Paper presented at: Heimann A, editor, Conference of Hermon investigators 1989-1990 (ed.), The Golan Research Institute, Qazrin, p. 15-16. Hebrew.

Werner YL 1993. Israel: bridge or barrier between African and Arabian sand deserts? Abstract 2nd World Congress of Herpetology, Adelaide.

Werner YL. 1995. A Guide to the reptiles and amphibians of Israel. Jerusalem: Nature Reserves Authority. Hebrew, scientific names for figures.

Werner YL. 1998. The herpetofauna in and near Israel: a personal review of advances (19861997), with new data. In: Fritz U, Obst FJ, Andreas B, editors. Contributions to a "Herpetologia arabica". Faunist Abh Staatl Mus Tierk Dresden. 21 (Suppl.):149-161.

Werner YL. 2004. A new species of the Acanthodactylus pardalis group (Reptilia: lacertidae) from Jordan. Zool Middle East. 32:39-45. 
Werner YL. 2007. Systematical interpretation of the geographical variation in the common hardun (Reptilia: agamidae: laudakia stellio). Hardun J Isr Herpetol Info Cent. 7:8-15. Hebrew; English abstract p. 110.

Werner YL. 2010. Taxonomic conclusions drawn from insufficient DNA specimen data could compromise tree-frog conservation. Mol Phylog Evol. 57:955-956.

Werner YL. 2011. Herpetology at a biogeographical junction: research and teaching at the Hebrew University of Jerusalem (Israel). Herp Rev. 42:150-159.

Werner YL. 2016. Reptile life in the land of Israel, with comments on adjacent regions. Frankfurt a. M.: Chimaira.

Werner YL, Avital E. 1980. The herpetofauna of Mt. Hermon and its altitudinal distribution. Isr J Zool. 29:192-193.

Werner YL, Babocsay G, Carmely H, Thuna M. 2006. Micrelaps in the southern Levant: variation, sexual dimorphism, and a new species (Reptilia: Ophidia: Atractaspididae). Zool Middle East. 38:29-48.

Werner YL, Frankenberg E, Shy E. 1998. Conservation-oriented herpetological research in Israel. Russ J Herpetol. 5:20-26.

Werner YL, Gajst O, Talbi R, Bouskila A. 2012. Acanthodactylus opheodurus in the Levant revisited, and the striped patterns of Levantine Acanthodactylus (Reptilia: Lacertidae). Zool Middle East. 56:31-38.

Werner YL, Korolker N, Sion G, Göçmen B. 2015. Bergmann's rule and Rensch's rule and the spurthighed tortoise (Testudo graeca). Biol J Linn Soc. 117:796-811.

Werner YL, Sion G 2008. The biogeographically heterogeneous herpetofauna of Israel (update 2008 for the 1988 survey area). Poster session presented at: First International Congress Documenting, Analysing and Managing Biodiversity in the Middle East, Aqaba, Jordan.

Werner YL, Sivan N, Kushnir-Bardugo V, Motro U. 1999. A statistical approach to variation in Cerastes (Ophidia: viperidae), with the description of two endemic subspecies. Kaupia (Darmstadt). 8:83-97.

Wiens J, Hutter J, Mulcahy CRD, Noonan G, Townsend BP, Sites TM, Reeder JW. 2012. Resolving the phylogeny of lizards and snakes (Squamata) with extensive sampling of genes and species. Biol Lett. 8:1043-1046.

Yom-Tov Y. 2011a. Biodiversity of Israel-a response to Roll et al. Isr J Ecol Evol. 57:181-182.

Yom-Tov Y. 2011b. Came to curse, but left blessing" A response to Roll et al.'s response to my response to Roll et al.'s (2009) article. Isr J Ecol Evol. 57:205-206.

Yom-Tov Y, Tchernov E, editors. 1988. The zoogeography of Israel. Dordrecht, Netherlands: Junk Publishers.

Yom-tov Y, Werner YL. 1996. Environmental correlates of the geographical distribution of terrestrial vertebrate species richness in Israel. Isr J Zool. 42:307-315.

Yosef R, Tryjanowski P. 2009. Avian species saturation on a long-term ringing station - a neverending story?. J Yamashina Inst Ornithol. 34:89-95.

Yosef R, Markovets M. 2009. Spring bird migration phenology in Eilat, Israel. ZooKeys. 31:193-210.

Zahavi A. 1990. Arabian babblers: the quest for social status in a cooperative breeder. In: Stacey PB, Koenig WD, editors. Cooperative breeding birds. Cambridge: Cambridge University Press; p. 105-130.

Zohary M. 1973. Geobotanical foundations of the Middle East. Vol. 2. Stuttgart: Gustav Fischer. 